\title{
1000 Norms Project: understanding foot and ankle health, disease and normality
}

\author{
Jennifer N Baldwin ${ }^{1 *}$, Marnee M McKay ${ }^{1}$, Claire E Hiller', Jean E Nightingale ${ }^{1}$, Niamh Moloney ${ }^{1}$, Natalie Vanicek', \\ Paulo Ferreira', Milena Simic ${ }^{1}$, Kathryn Refshauge ${ }^{1}$, Joshua Burns ${ }^{1,2}$, the 1000 Norms Project Consortium $^{1}$ \\ From 4th Congress of the International Foot and Ankle Biomechanics (i-FAB) Community \\ Busan, Korea. 8-11 April 2014
}

A primary goal of healthcare is to understand the boundaries of health and normality and identify when abnormalities are harmful. Diagnosis of disease or impairment is often made by comparing results from clinical measures with healthy reference values. At present there is a great need for comprehensive lower limb reference data representing the healthy population. The 1000 Norms Project is currently recruiting to provide reference values for a set of widely-used clinical and biomechanical measures of the foot and ankle. A volunteer sample of 1000 healthy individuals between the ages of 3 and 100 years is participating in the Project. Measures of plantar pressure, gait, ankle range of motion, foot and ankle muscle strength, foot posture and ankle instability are included in the comprehensive battery of items (Table 1).

The 1000 Norms Project reliability study was completed in November 2013. Inter-rater reliability was found to be excellent (ICC >.75) for all foot and ankle measures (Table 2). Recruitment and data collection will take place over the next two years. The release of the final database to the international community via a secure, free online network is anticipated to occur in March 2016. The 1000 Norms Project will provide a substantial contribution to our understanding of the range of normal foot and ankle function in healthy individuals. The reference dataset will be a useful tool for disease diagnosis and management, health surveillance

Table 1 Foot and ankle items assessed in the 1000 Norms Project

\begin{tabular}{|c|c|c|}
\hline Item & Item Description & Measurement variables \\
\hline $\begin{array}{l}\text { Plantar } \\
\text { pressure }\end{array}$ & $\begin{array}{l}\text { Collection of plantar pressure during gait using two-step protocol and } \\
\text { Emed pressure platform (Novel) }\end{array}$ & $\begin{array}{l}\text { Peak pressure, mean pressure and pressure-time } \\
\text { integral at different regions of the foot }\end{array}$ \\
\hline $\begin{array}{l}\text { Ankle range } \\
\text { of motion }\end{array}$ & $\begin{array}{l}\text { Active ankle plantarflexion measured using goniometry } \\
\text { Passive ankle dorsiflexion measured using weight-bearing lunge test }\end{array}$ & $\begin{array}{l}\text { Plantarflexion angle in degrees } \\
\text { Dorsiflexion angle in degrees }\end{array}$ \\
\hline $\begin{array}{l}\text { Ankle } \\
\text { strength }\end{array}$ & $\begin{array}{l}\text { Plantarflexion strength assessed using fixed dynamometry } \\
\text { Dorsiflexion strength assessed using handheld dynamometry }\end{array}$ & $\begin{array}{l}\text { Results from three trials presented as raw data in } \\
\text { Newtons and also normalised to body weight }\end{array}$ \\
\hline $\begin{array}{l}\text { Toe flexor } \\
\text { strength }\end{array}$ & Paper Grip Test assessing strength of hallux and four lesser toes & $\begin{array}{l}\text { Pass/fail score recorded for ability to grip paper under } \\
\text { toes }\end{array}$ \\
\hline Gait & $\begin{array}{l}\text { Spatio-temporal aspects of gait measured using Zeno walkway } \\
\text { (Protokinetics) }\end{array}$ & $\begin{array}{l}\text { Step time, step length and width, gait velocity and foot } \\
\text { progression angle }\end{array}$ \\
\hline Foot posture & Foot Posture Index consisting of six assessments relating to foot posture & $\begin{array}{l}\text { Foot posture graded on a 15-point scale from }-12 \\
\text { (varus) to }+12 \text { (valgus) }\end{array}$ \\
\hline $\begin{array}{l}\text { Ankle } \\
\text { instability }\end{array}$ & $\begin{array}{l}\text { Cumberland Ankle Instability Tool (Adult and Youth versions) consisting of } \\
9 \text { items pertaining to self-perception of ankle stability }\end{array}$ & $\begin{array}{l}\text { Overall score out of } 30 \text { where higher scores indicate } \\
\text { greater instability }\end{array}$ \\
\hline
\end{tabular}

\footnotetext{
* Correspondence: jbal2575@uni.sydney.edu.au

${ }^{1}$ Arthritis and Musculoskeletal Research Group, Faculty of Health Sciences,

The University of Sydney, Australia

Full list of author information is available at the end of the article
} 
Table 2 Inter-rater reliability of foot and ankle items assessed in the 1000 Norms Project

\begin{tabular}{llll}
\hline Item & ICC (95\% CI) & SEM & SEM \% mean \\
\hline Ankle plantarflexion ROM & $.885(.538-.971)$ & 1.36 & 2.2 \\
Ankle dorsiflexion lunge test & $.875(.498-.969)$ & 1.73 & 4.8 \\
Dorsiflexion strength & $.958(.831-.990)$ & 4.36 & 2.9 \\
Plantarflexion strength & $.973(.892-.993)$ & 3.57 & 1.9 \\
Foot Posture Index Left & $.978(.916-.994)$ & 0.09 & 2.0 \\
Total Score & & & \\
$\begin{array}{l}\text { Foot Posture Index Right } \\
\text { Total Score }\end{array}$ & $.958(.820-.990)$ & 0.14 & 3.3 \\
\hline
\end{tabular}

Note: ROM, range of motion; ICC, Intraclass Correlation Coefficient (95\% Confidence Interval); SEM, Standard Error of Measurement; SEM \% mean, Standard Error of Measurement expressed as a percentage of the mean

and future outcome measure development for clinical trials of rehabilitative, surgical and pharmacological interventions.

\section{Authors' details}

${ }^{1}$ Arthritis and Musculoskeletal Research Group, Faculty of Health Sciences,

The University of Sydney, Australia. ${ }^{2}$ Institute for Neurosciences and Muscle

Research, The Children's Hospital at Westmead, Australia.

Published: 8 April 2014

doi:10.1186/1757-1146-7-S1-A6

Cite this article as: Baldwin et al:: 1000 Norms Project: understanding

foot and ankle health, disease and normality. Journal of Foot and Ankle

Research 2014 7(Suppl 1):A6.

Submit your next manuscript to BioMed Central and take full advantage of:

- Convenient online submission

- Thorough peer review

- No space constraints or color figure charges

- Immediate publication on acceptance

- Inclusion in PubMed, CAS, Scopus and Google Scholar

- Research which is freely available for redistribution

Submit your manuscript at www.biomedcentral.com/submit
C Biomed Central 